\title{
Editorial: Reflections on Islamophobia in Central and Eastern Europe
}

\section{PřemysI Rosůlek}

University of West Bohemia in Pilsen

Islamophobia is a rather new term in scholarly fields but it is an old concept (Cesari 2009; López 2011, 569). All the variants of Islam and Muslims were perceived as a threat in Europe from its arrival in 7 th century to at least second half of the 16th century (Said 2003, 59, 75) after the decisive bottle by Lepante as a turning point meant the irreversible retreat of Islam and Muslims from Europe. In the Renaissance period, the process of othering the Muslims and Islam [mainly - and rather undistinguishably - Ottomans or Persians] in an old continent was not any more based primarily on fear or the "true believers and infidels" divide, but the European perception of Islam transferred into civilizational differences emphasizing both "our" ancient Greek period and Hellas contrary to "them" labeled with the adjective "barbaric", a notion typical for early modern literature (Lewis 1993, 25). Similarly, Maria Todorova describes "English images of the Turks during the sixteenth and much of the seventeenth centuries were ones of tyranny, arbitrariness, extortions, slavery, piracy, savage punishments, and Christian ordeals; they were also images of strangeness and a diatribe against Islam" (Todorova 2009, 90). The forthcoming era of Enlightenment founded on anticlericalism and a critique of religion further worsened the image of Islam in Europe. In that age, the decaying Ottoman Empire heavily contributed to the shared view in Europe of its despotic character, "the unreformability of the Muslim religion, afflicted with fanaticism and bigotry" (Todorova 2009, 76). Similarly, during the 19th and 20th centuries, the stereotyping image of "the mythical Orient" with the widely shared anti-Arabic and anti-Islamic prejudices further strengthened by the clashes between Arabs and Zionism, as Edward Said famously argued in his book Orientalism, became deeply embodied in the western history of orientalism (Said 2003, 27).

Edward Said's critical view on the widely accepted image in the West, which associated Islam with negative stereotypes fully conformed to emerging postcolonial and postmodern theories aimed at the deconstruction of European grand narratives and its conviction of (whether former colonial or newly neo-imperial) supremacy over the rest of the world. Nevertheless, I

\footnotetext{
* Přemysl Rosůlek, University of West Bohemia in Pilsen, Jungmannova 1, 30100 Plzeň, Czech Republic; rosulek@kap.zcu.cz
} 
assume that two remarks shall be emphasized for the development of the issue in the subsequent two to three decades after Said's invention of orientalist discourse - first, events which shaped Islamophobia (though the term was not properly conceptualized yet by then) at grassroots level and, second, the scholarly debate on the Islamophobia phenomenon seriously considered from the late 1990s. ${ }^{1}$

First, in the West, the vox populi on Islam and Muslims was shaped by the chain of events starting with the dramatic 1979 Islamic revolution in Iran and its most spectacular political act echoed in the West, when the fatwa issued by the Iranian leader, Ayatollah Khomeini, against Salman Rushdie for allegedly blasphemy in early 1989 turned into highly politicized phenomenon in (western) Europe (Shadid 2006, 14). Consequently, Islam as such began to be strongly associated with intolerance and bigotry (Betz 1994, 94). In the same year, three girls attempted to enter their middle school wearing headscarves in France which turned into highly debated affair. Further, in the first decade of the new millennium, in the West, the bad reputation of the Taliban in Afghanistan did not contribute to a good image of Muslims and Islam. The 2005 French riots in Les Banlieues de l' islam, the Jyllands-Posten Muhammad cartoons controversy, the murder of the film-maker Theo van Gogh in Amsterdam, threats to Dutch MP Ayaan Hirsi Ali and, mainly, spectacular terrorist attacks of Al-Qaeda in the USA, Madrid and London (Mamadouh 2012, 390) which were later followed by similar attacks in Brussels, Paris and Berlin were also contributing factors. Additionally, governments actively responding to the threat of Islamic terrorism by the tightening of security policies in Europe strengthened the image of Muslims as terrorists (Cesari 2009), which also strongly occupied media discourse (Green 2015, 233-265). As a direct consequence of the disastrous development of the Arab Spring phenomenon and analogously with the emergence and impact of the serious conflicts in Syria, Afghanistan and Iraq, the terms Muslim and Immigrant (Cesari 2009, 2) became synonyms at street level and not seldom in the rhetoric of political elites which applied also to the terms Islam and refugees (Yilmaz 2016, 19). And lastly, the emergence of current events labeled either as the "refugee crisis" or as the "migration crisis" in Europe was originally epitomized by negative scenarios, as were the mediaeval brutality of the ISIS in the Middle East and elsewhere or the infinite and incomprehensible conflicts on the territory of disintegrated Syria and as well as breakdown of Libya and its anarchic feature.

1 It is beyond the scope of this editorial to mention debates and critical remarks on orientalism, neoorientalism and post-orientalism. See e.g. Dabashi 2019 or Samiei 2010. 
Second, from the scholarly point of view, western academicians did not start to elaborate on the Islamophobia phenomenon seriously before the 1997 report titled Islamophobia: A Challenge for Us All issued by the British NGO the Runnymede Trust which - founded back in late 1960s - is focused on race relations and equality (López 2011, 556; Kaya 2015, 451). However, shortly afterwards Islam gained a prominent position in social sciences (Shadid 2006, 12).

A rather large amount of studies related to Islamophobia issued in the West has been debated among scholars. They can be categorized into the three fundamental areas of time, space and social groups (Bleich 2012, 182) to which, as I am convinced, debate on the accuracy of the term Islamophobia shall be added.

First, and rather paradoxically, there have been discussions focused exclusively or predominantly on the term Islamophobia. Basically, these publications are aimed at two fundamental areas: on elaboration of the better definition of Islamophobia than there are available so far; or, on scholarly suggestion aimed at more precise terms which can encompass the phenomenon on the expanse of the unappropriated word Islamophobia (López 2011, 556, 557). Apart from that, context also matters as the texts broadly busy with definition are commonly investigating relation either to -isms, i.e. ideological aspects of the phenomenon - xenophobia, anti-Semitism and racism (Renton and Gidley 2017; Fekete 2009; Bakali 2016; Carr 2016) or its uneasy relationship with various facets of liberal political theory for pluralistic societies, i.e. intolerance, discrimination and victimization (Ernst 2013; Esposito and Kalin 2011; Zempi and Chakraborti 2014; Zempi and Awan 2016).

Second, texts linked to the time dimension are analysis of Islamophobia and its manifestations in different historical epochs from the early mediaeval time until the contemporary age "beyond terror" (Tyrer 2013). Apart from the already mentioned seminal work Orientalism from 1978 written by Edward Said, there are numerous publications focused on the history of ideas which analyze either the fundamental pillars of the "old concepts" of Colonialism and Orientalism (Kumar 2012) or emphasize the predominantly paradigmatic shift from the former Occident-Orient construction of Orientalism invented by Edward Said to a contemporary more deterritorialized and interconnected period of neo-Orientalism which feeds Islamophobia with new agendas (Kerboua 2016; Samiei 2010) or, alternatively, how Islamophobia has been reframed in the post-political age (Tyrer 2013) and in the postcolonial environment contrary to the former colonial approach (Meer 2014).

Third, as for the space dimension, there have been numerous texts published focused on macro- or micro-level issues. Concretely, texts are aimed at e.g. 
the global or international environment (Morgan and Poynting 2012), at the Western (Green 2015; Hardy and Mughal and Markiewicz 2017) or at the European - here predominantly intended as western European - realm (Fekete 2009; Renton and Gidley 2017) and further at case studies focused on countries strongly prioritizing the U.S. (Love 2017; Ernst 2013; Ali 2012; Beydoun 2018) and western European countries, predominantly the U.K. (Jackson 2018; Abbas 2011) to focus on regional or local issues (Jackson 2018; Al-Natour and Morgans 2012). Apart from the publications related to case studies, a number of comparative texts were published (Cesari 2011; Cherribi 2011) or publications with chapters regarding numerous western countries (see e.g. Esposito and Kalin 2011).

Fourth, texts analyzing social groups in relation to Islamophobia could be further differentiated into various subcategories across social strata, e.g. the European extreme right (Zuquete 2008) or youth culture (Bakali 2016; Ramberg 2004).

Apart from these four ground areas of research on Islamophobia, there shall be also mentioned that the dramatic $9 / 11$ terrorist attacks aimed at symbolical global targets and its direct medialization encouraged the media to actively participate in the construction of the "Islamophobic Industry" (Lean 2012), fostering the "culture of security" and the spreading of "moral panic" deepened Islamophobic trends in the West. The spectacular 9/11 events and the subsequent "War on Terror" transformed the Islamophobia phenomenon from a domain exclusively reserved to populist radical right parties into a larger political mainstream in the West (Mudde 2007, 84) and belonged to a decisive cause, triggering the securitization of states' political agendas (Mudde 2013, 9). At the same time, analogously and logically, social scientists intensified their research interest on Islam specially with linkage to the terms radicalism and terrorism which enabled the constitution of a new filed of research. In parallel, a rising number of security analysts and think-tanks started to produce numerous publications on Islam and Muslims in relation to Islamic terrorism, Osama bin-Laden and Al-Qaeda (Lean 2012; Öktem 2011, 155-156).

Nevertheless, as Serdar Kaya rather courageously asserts, valuable research on Islamophobia had not emerged before 9/11 (Kaya 2015, 452). He further claimed recently that vast majority of the texts related to that phenomenon remain "single or comparative country case studies", while the "more systematic and quantitatively driven cross-country studies on anti-Muslim prejudices are less common, and the systematic studies that also include the country-level factors are almost exceptional" (Kaya 2015, 452). This is 
debatable or even disputable for western scholars, however, his criticism can be fully applied to the scarce number of academic works on Islamophobia issued so far in Central and Eastern Europe (CEE).

As for the CEE context, apart from Russia, post-Soviet areas and the Balkans, there was scarce evidence of scholarly interest and literature on Islamophobia there until recently. Ivan Kalmar commented on the very recent situation as follows:

Although the severity of the Islamophobia evidenced in the response of the political leaders and the public in CEE was recognized everywhere, very little academic research had immediately been done on it either in the East or in the West. It is in order to remedy this situation that I applied for and got a grant from the Social Sciences and Humanities Research Council of Canada to investigate the phenomenon. When we held a preliminary meeting in Prague in 2016, it was quite difficult to find scholars engaged with the issue (Kalmar 2018: 97).

However, as Kalmar further asserts, the situation has changed rapidly since. The advent of the "migration crisis" in CEE at around the middle of 2015 impacted, firstly, rhetoric exercised and policies exhibited by local political elites, secondly, public debates, and thirdly, logically, also attracted the attention of the social science scholars who finally started to contribute texts on the issue of Islamophobia. However, for readers limited to the accessibility of texts written in English ${ }^{2}$, there is still rather scarce evidence of works focused predominantly on Islamophobia in CEE with a comparative perspective (e.g. Hafez 2018; Moreno 2010; Černý 2017; Harris and Jackson and Piekut and Valentine 2017; Mareš 2014) which applies also to case studies devoted to separate countries - The Czech Republic (e.g. Donatella 2015; Rosůlek 2018), Poland (e.g. Narkowicz and Pędziwiatr 2015; 2017), Hungary (e.g. Vidra 2017) or Slovakia (e.g. Kluknavská and Smolík 2016).

To sum up, in the still under-researched field of Islamophobia in CEE there is a demand for a more "in-depth" analysis of both case studies and crossnational comparisons which can be achieved through scholarly collaboration.

2 For those who can read books written in the Czech language see e.g. by Ostřanský, Bronislav (ed.). 2018. Islamofobie po česku [Islamophobia on the Czech way] published in Vyšehrad (Praha) and by Rosůlek, Přemysl (ed.). 2017. Sondy do studia Islámu v obdobi “migrační krize” [Investigations into the Study of Islam During ,the Migration Crisis”] published in Dokořan (Praha) and journal article written by Krčál, Petr and Naxera, Vladimír. 2018. "Populistická konstrukce národa ohroženého migrací: CAQDAS volebního diskurzu českých parlamentních voleb v roce 2017” [Populist Construction of Nation Threatened by the Migration: CAQDAS Electoral Discourse of the Czech Parliamentary Elections in 2017] published in Sociológia 50 (5): 491-523. I am sure there are other relevant texts mainly in the Hungarian language - which are also beyond my reach. 
I assume that the three articles in this special section of the JNMLP peerreviewed journal would contribute to bridging the existing lack of texts on the issue and would support better understanding of Islamophobia in the CEE realm.

First a text with comparative ambitions encompassing the Eastern European perspective (nevertheless, despite of the used notion "Eastern", countries analyzed here may be surely considered as "Central" European also) in general will be introduced. Gert Pickel from Leipzig University and Cemal Öztürk from the Leuphana University of Lüneburg in their article titled Islamophobia Without Muslims? The "Contact Hypothesis" as an Explanation for Anti-Muslim Attitudes - Eastern European Societies in a Comparative Perspective argue that CEE societies are more prone to Islamophobia on an individual and societal level despite of the reality that these societies are (almost) without Muslims. Their explanation is based on data taken from the European Social Survey (2014) and analogously recounting social psychological theories which deal with prejudice and stereotyping, they convincingly argue that lack of "reallife experience" is a supporting factor to negative stereotypes about Muslims and, on the contrary, "individuals who are in contact with outside groups, make friends with people from other ethnicities, and perceive these contacts as convenient are less likely to feel prejudice toward Muslims." Further, the media and populist leaders shape anti-Muslim attitudes in these societies (such as Miloš Zeman: see the second text in the special section written by Vladimír Naxera and Petr Krčál where Jaroslaw Kaczyński and Victor Orbán are explicitly mentioned) in order to easily attract prejudiced voters. They noted this phenomenon spread by political elites as "xenophobic nationalism" which is epitomized by anti-European, nationalistic, xenophobic and anti-Muslim attitudes and raises two issues (negative political consequences, to be further discussed) - first, the possible negative consequences of the euroscepticism among the V4 group for its relations to the EU and, second, whether - and perhaps, to which extent - Islamophobia enhances Euroscepticism in CEE.

Second, Vladimír Naxera and Petr Krčál from the University of West Bohemia in Pilsen contributed to the debate with the text titled rather emotionally "This is a Controlled Invasion": The Czech President Miloš Zeman's Populist Perception of Islam and Immigration as Security Threats. They introduced an academic text analyzing the strategy of the Czech President Miloš Zeman using the term "security" in his "speeches, interviews, statements, and so on," during his first term in office (2013-2017) with the help of a data set processed by MAXQDA11+. The authors argue that "security" used in Zeman's argumentation is primarily related to the phenomenon of Islam and 
immigration which both represent "the absolute largest threat to contemporary Europe." Though having analyzed only the Czech President Miloš Zeman, Naxera and Krčál argue in a similar vein to Gert Pickel and Cemal Öztürk (see the first text of the special section), where in both texts there is a clear link between CEE leaders and the principles used by right-wing populists in Europe. Interestingly, in-depth analysis of Zeman's frequent use of the term "security" during his first presidential mandate revealed another aspect - his changing relationship with Russia. Initially, it was perceived as a threat ("although in the beginning of his presidential function, he labeled Russia as a security problem on several occasions"), Zeman later gradually shifted his approach to relativize Russia as a security threat to the point that he ceased to consider it as a source of danger completely.

Third and finally, Lubomír Zvada from Palacký University in Olomouc in the Czech Republic contributed to the special section with the text called Securitization of the Migration Crisis and Islamophobic Rhetoric: The 2016 Slovak Parliamentary Elections as a Case Study. Zvada focuses on the "migration crisis" in Slovakia and thus his contribution brings to an end the focus on the CEE realm. Unlike the two previous texts introduced already in this editorial for which a focus on Slovakia would be far beyond their scope of interest, Zvada's publication on Slovakia draws readers' attention nearer to the perspective of this country through the lenses of a theory of securitization and the process applied to the 2016 general elections there. Zvada's approach is valuable also for his attention paid to, first, the party which could be - in CEE reality - considered not only as that dominating Slovak politics but also as the "social democratic" one, Direction-SD, and second, to three another relevant political parties which may be characterized as on the nationalistic wave either as the nationalist Slovak National Party or as the national conservative We Are Family-Boris Kollár or as the far-right political party Kotleba-Peoples' Party Our Slovakia. Therefore, there is no surprise that author found out that the electoral campaigns of the two nationalistic and one extremist party were characterized by "extremely anti-Muslim an anti-Islam rhetoric". However, contrary to the western type of social democratic parties (and in compliance with the former head of social democratic party and today's president of the Czech Republic Miloš Zeman), the Slovakian "social democratic party", Direction-SD, as a ruling party "was the main actor in the securitization of the migration crisis in the Slovak Republic" despite the fact that Direction-SD "did not transform migration issues to their political agenda" prior to 2016 elections. Zvada reveals the rhetoric of the Direction-SD party and its leader (and the Prime Minister) Robert Fico and found no significant differences to other nationalist parties under his investigation. From the point of view of 
Direction-SD, Muslims are linked to terrorism (see linkage to both previous articles), immigrants and their mosques would change the Christian character of our country and multiculturalism in Europe has failed. In Zvada's text, there are similar findings in the rhetoric of nationalist parties in Slovakia to the rhetoric of Miloš Zeman analyzed by Naxera and Krčál in the second text of this special section (linkage between Muslims and terrorists) and to the civilizational notion of "Christian identity" or "Christian heritage" which were observed by Gert Pickel and Cemal Öztürk in their analysis of CEE leaders. Nevertheless, Islam as a perceived threat to Christianity is in the Slovakian context is mentioned analogously to anti-Semitism which in 1930s - quoting argumentation of the Slovakian social scholar Jozef Lenč - helped to destroy democracy in Slovakia and contributed to the rise of the subsequent totalitarianism there.

\section{Acknowledgements}

I would like to thank Farid Hafez from the University of Salzburg and Alexander Yendell from the University of Leipzig for their work related to a Call for Papers on Islamophobia in CEE. Nevertheless, I must clarify that neither F. Hafez nor A. Yendell are responsible for the content of this editorial. Therefore, any doubts and concerns - if applied - may be addressed solely to me personally.

\section{References}

Abbas, Tahir. 2011. Islamophobia in the United Kingdom: Historical and Contemporary Political and Media Discourses in the Framing of a 21st-Century Anti-Muslim Racism. In Esposito, John L. and Kalin, Ibrahim (eds.). Islamophobia: The Challenge of Pluralism in the 21st Century. Oxford and New York: Oxford University Press, 63-76.

Ali, Yaser. 2012. "Shariah and Citizenship - How Islamophobia Is Creating a Second-Class Citizenry in America," Californian Law Review 100 (4): 1027-1068.

Al-Natour, Ryan J. and Morgans, George. 2012. New South Wales. In: Morgan, George and Poynting Scott (eds.). Global Islamophobia: Muslims and Moral Panic in the West. Farnham and Burlington: Ashgate, 101-117.

Bakali, Naved. 2016. Islamophobia: Understanding Anti-Muslim Racism through the Lived Experiences of Muslim Youth. Rotterdam: Sense Publishers.

Betz, Hans-George: 1994. Radical Right-Wing Populism in Western Europe. New York: St. Martin's Press.

Beydoun, Khaled A. 2018. American Islamophobia. Understanding the Roots and Rise of Fear. Oakland: University of California Press.

Bleich, Erik. 2012. "Defining and Reseraching Islamophobia." Review of Middle East Studies 46 (2): 180-199. 
Carr, James. 2016. Experiences of Islamophobia: Living with Racism in the Neoliberal Era. Routledge: Abingdon and New York.

Cesari, Jocelyne. 2009. The Securitization of Islam in Europe. Research Paper No. 15, CEPS Programme. Challenge Liberty Security. Accessed October 10.2018. http://aei.pitt. edu/10763/1/1826.pdf.

Cesari, Joceline. 2011. "Islamophobia in the West: A Comparision between Europe and the United States." In Islamophobia, edited by John L. Esposito, Ibrahim Kalin, 21-43. Oxford and New York: Oxford University Press.

Cherribi, Sam. 2011. An Obsession Renewed: Islamophobia in the Netherlands, Austria, and Germany. Esposito, John L. and Kalin, Ibrahim (eds.). Islamophobia: The Challenge of Pluralism in the 21st Century. Oxford and New York: Oxford University Press.

Černý, Karel. 2017. "Anti-semitism yesterday and Islamophobia today. A Central European Perspective." RUDN Journal of Sociology. 17 (3): 399-407.

Dabashi, Hamid. 2009. Post-Orientalism: Knowledge and Power in Time of Terror. New Brunswick and London: Transaction Publishers.

Donatella, Bonansinga. 2015. "The role of public discourse in threat framing: the case of Islamophobia in Czech Republic”. International Journal of Arts and Sciences 8 (8): 107-117.

Ernst, Carl W. (eds.). 2013. Islamophobia in America: The Anatomy of Intolerance. New York: Palgrave MacMillan.

Esposito, John L. and Kalin, Ibrahim (eds.). 2011. Islamophobia: The Challenge of Pluralism in the 21st Century. Oxford and New York: Oxford University Press.

Fekete, Liz. 2009. A Suitable Enemy. Racism, Migration and Islamophobia in Europe. London and New York: Pluto Press.

Green, Todd H. 2015. The Fear of Islam. An Introduction to Islamophobia in the West Minneapolis: Fortress Press.

Hafez, Farid. 2018. "Street-level and government-level Islamophobia in the Visegrád Four countries." Patterns of Prejudice (published online 6 November 2018).

Hardy, Mike and Mughal, Fiyaz and Markiewicz, Sarah (eds.). 2017. Muslim Identity in a Turbulent Age. Islamic Extremism and Western Islamophobia. London and Philadelphia: Jessica Kingsley Publishers.

Harris, Catherine and Jackson, Lucy and Piekut, Aneta and Valentine, Gill. 2017. "Attitudes towards the 'stranger': negotiating encounters with difference in the UK and Poland." Social \& Cultural Geography 18 (1): 16-33.

Jackson, Leonie B. 2018. Islamophobia at the Local Level: The Case of Dudley Mosque. In Jackson, Leonie B. 2011. Islamophobia in Britain: The Making of Muslim Enemy. Palgrave Macmillan, 59-83.

Jackson, Leonie B. 2011. Islamophobia in Britain: The Making of Muslim Enemy. Palgrave Macmillan.

Kalmar Ivan. 2018. "On Islamophobia in CEE countries. Interview with Prof. Ivan Kalmar”. Rozhovor [interview (by Přemysl Rosůlek)]. Acta FF, 10 (1): 97-100.

Kaya, Serdar. 2015. "Islamophobia in Western Europe: A Comparative, Multilevel Study." Journal of Muslim Minority Affairs. 35 (3): 450-465. 


\section{Journal of Nationalism, Memory \& Language Politics 12(2)}

Kerboua, Selim. 2016. "From Orientalism to neo-Orientalism: Early and contemporary construction of Islam and the Muslim world." Intellectual Discourse 24 (1): 7-34.

Kumar, Deepa. 2012. Islamophobia and the Politics of Empire. Chicago: Haymarket Books.

Kluknavská, Alena and Smolík, Josef. 2016. "We hate them all? Issue adaptation of extreme right parties in Slovakia 1993-2016." Communist and Post-Communist Studies 49 (4): 335344.

Lean, Nathan. 2012. The Islamophobia Industry: How the Right Manufactures Fear of Muslims. London: Pluto Press.

Lewis, Bernard. 1993. Islam and the West. Oxford-New York: Oxford University Press.

López, Fernando Bravo. 2011. "Towards a definition of Islamophobia: approximations of the early twentieth century." Ethnic and Racial Studies 34 (4): 556-573.

Mamadouh, Virginie. 2012. "The Scaling of the Invasion: A Geopolitics of Immigration Narratives in France and the Netherlands." Geopolitics 17 (2): 377-401.

Love, Erik. 2017. Islamophobia an Racism in America. New York. New York University.

Mareš, Miroslav. 2014. "The extreme right's relationship with Islam and Islamism in EastCentral Europe: from allies to enemies', East European Politics and Societies and Cultures" 28 (1): 205-224.

Meer, Nasar. 2014. "Islamophobia and postcolonialism: continuity, Orientalism and Muslim consciousness.” Patterns of Prejudice, 48 (5): 500-515.

Morgan, George and Poynting Scott (eds.). 2012 Global Islamophobia: Muslims and Moral

Panic in the West. Farnham and Burlington: Ashgate.

Moreno, Leora. 2010. "Fearing the Future: Islamophobia in Central Europe". New Presence: The Prague Journal of Central European Affairs. 12 (3): 73-80.

Mudde, Cas. 2007. The Populist Radical Right in Europe. Cambridge: Cambridge University Press

Mudde, Cas. 2013. "Three decades of populist radical right parties in Western Europe: So what?" European Journal of Political Research 52: 1-19.

Narkowicz, Kasia and Pędziwiatr, Konrad. 2017. "From unproblematic to contentious: mosques in Poland.” Journal of Ethnic \& Migration Studies 43 (3): 441-457.

Narkowicz, Kasia and Pędziwiatr, Konrad. 2015. "Saving and fearing Muslim women in 'post-communist' Poland: troubling Catholic and secular Islamophobia." Gender, Place \& Culture: A Journal of Feminist Geography. 24 (2): 288-299.

Öktem, Kerem. 2011. "Between emigration, de-Islamizatoin and the nation-state: Muslim communities in the Balkans Today." Southeast European and Black Sea Studies 11 (2): 155171.

Ramberg, Ingrid. 2004. Islamophobia and Its Consequences on Young People. Marseille: Council of Europe.

Renton, James and Gidley, Ben (eds.). 2017. Antisemitism and Islamophobia in Europe. A Shared Story? London: Palgrave Macmillan.

Rosůlek, Přemysl. 2018. "The Czech Singers Critical of Islam and Refugees on Facebook in the Age of the "Migration Crisis" (2015-2017)." Politics in Central Europe 14 (1): 35-62. 
Said, Edward. 2003 [1978]. Orientalism. London - New York: Penguin Books.

Samiei, Mohammad. 2010. "Neo-Orientalism? The relationship between the West and Islam in our globalised world." Third World Quarterly 31 (7): 1145-1160.

Shadid, Wasif A. 2006. "Public Debates over Islam and the Awereness of Muslim Identity in the Netherlands." European Education 38 (2): 10-22.

Todorova, Maria. 2009. Imagining the Balkans. Oxford: Oxford University Press.

Tyrer, David. 2013. The Politics of Islamophobia. Race, Power and Fantasy. New York: Pluto Press.

Vidra, Zsuzsanna. 2017. Counter-Islamophobia Kit. Workstream 1: Dominant Islamophobic Narratives - Hungary. CIK Project (Counter Islamophobia Kit) Working Paper 7: CERS, 2017. Accessed 10 November 2018. https:/cik.leeds.ac.uk/wp-content/uploads/ sites/36/2017/07/2017.07.26-WS1-Hungary-Final.pdf.

Yilmaz, Ferruh. 2016. How the Workres Became Muslims: Immigration, Culture, and Hegemonic Transformation in Europe. Michigan: Michigan University Press.

Zempi, Irene and Awan, Imran. 2016. Islamophobia: Lived Experiences of Online and Offline Victimisation. Bristol and Chicago: Policy Press.

Zempi, Irene and Chakraborti, Neil. 2014. Islamophobia, Victimisation and the Veil. Basingstoke: Palgrave Macmillan.

Zuquete Jose Pedro. 2008. “European extreme Right and Islam: New Directions?” Jounal of Political Ideologies 13 (3): 321-344. 